DRAFT VERSION: please refer to the forthcoming published version in Gephart, W. (ed., 2020), In the Realm of Corona Normativities

\title{
Sacred Euro:
}

\section{Sovereign Debt(s) and EU's Bare Credit in the Corona Crisis}

Valentino Cattelan

\section{Introduction. Money, Nomisma and Nomos}

Far from being a neutral medium of exchange, money affects the daily practice of our economic dealings while being intrinsically connected to the whole of legal, social, and political interactions of the community to which we belong. In this light money enjoys its own morality, where voluntary customary usage ('moral' from the Latin mos, 'manner, custom') is backed by the subsistence of a normative order, a nomos: the former and the latter being collectively practiced, shared and endorsed in a certain social group. Hence, sovereign power (the beholder of the law) can hardly posit the use of 'fiat money' by decree when mechanisms of inflation, mistrust, recession or even depression are in action. Here 'positive money' (money imposed by the state) contrasts 'monetary nomos' and, then, it is soon replaced by alternative 'natural money' that can better work as store of value (for instance, commodities such as precious metals, gold or silver), unit of account and means of exchange (the rise of cryptocurrencies, e.g. bitcoins, represents the most recent example in this direction). It is indeed the criterion of public trust that fosters the morality of positive money by its convergence with natural money: the public gives political credit to the sovereign to the extent to which through its nomisma (currency as 'monetary nomos') people can trust receiving economic credit in the reciprocity of their dealings. In doing so they use money as something that represents (as store of value, unit of account and means of exchange) their shared/mutual needs in/for participating in the same community. A conceptual equivalence with the jurisprudential couple 'positive law'/"natural law' (that kind of 
sovereign law whose legitimacy derives from providing 'what is right', to wit, 'rights') can be easily implied from the previous reflection, a point on which I will come back later.

Aristotle, in his Nicomachean Ethics, underlines the deep intersection between monetary practice and normative/social order (what the elision 'monetary nomos' actually describes) by noting the etymological correspondence in Greek language between 'currency' (nomisma) and 'law' (nomos), both related to the need for the subsistence in any given community of a standard for exchanges and social relations established by common agreement.

There must... be one standard by which all commodities are measured... money has become by convention a sort of representative of common need (demand); and this is why it has the name 'money' [nomisma, customary currency] - since it exists not by nature [physis] but by 'law' [nomos, 'custom, usage, law as natural/social order', distinct from lex posita or ius positum]. ${ }^{1}$

Moving from these preliminary considerations this paper aims to shed some light over the Corona crisis by applying a law-as-culture paradigm to the European Union and its money. To this specific objective it interprets the impact of the emergency by depicting the EU as a polity whose 'positive money', the Euro, seems still unable today to function as 'natural money': that is to say, a polity still lacking in a full monetary nomos. In particular, this contribution argues that the current pandemic has revealed the persistently contradictory nature of the Euro as a kind of sacred money (nummus sacer) ${ }^{2}$ that may be borrowed by member states via sovereign $\operatorname{debt}(\mathrm{s})$, but whose credit is not backed (yet) by the EU polity as a whole $(\S 3)$ : a condition of sacertas that the recovery plan proposed by the EU Commission at the end of May 2020 may actually overcome, in a sort of 'return to Life' (if not a resurrection) for the EU political project as grounded on solidarity ( $(5)$.

Besides drawing from the scholarship by Giorgio Agamben, ${ }^{3}$ valuable hints for some conclusive remarks will be found in George Simmel and Marcel Mauss. More precisely, by locating the discussion of the 'sacred Euro' ( $(3)$ in-between the chronicle of the first version of the EU Coronavirus relief deal (as agreed on by the Eurogroup on Thursday $9^{\text {th }}$ April 2020) and the final proposal of its contents by the EU Commission, the paper will move from a critique to the

\footnotetext{
${ }^{1}$ Aristotle: Nicomachean Ethics, Book V, 1133a 29-30.

2 The etymology of the Latin word nummus, 'coin', relates to the Greek nomisma too.

${ }^{3}$ To which the title of this paper clearly refers by paraphrasing his Homo Sacer: Sovereign Power and Bare Life.
} 
bailout system embedded in the ESM loans model (as a signal of the political failure of the Euro as monetary nomos: $\S 2$ ) to an appraisal of the recovery plan in terms of an embryonic full nomisma for the EU polity ( $(4)$. Accordingly, while by highlighting the failure of the European nomos/nomisma the 'bare credit' of the EU will be related to an inescapable revival of nationalism and of the sovereign power in the member states, the resurgence of the EU political project will be linked, on the contrary, to the re-discovery of solidarity as its founding value ( $\S$ 5). This 'return to Life' will be conceived in connection to more ambitious actions to be taken, so to fully transform the nomos of the EU market into that of the EU polity: a radical transformation that may be actually ignited, as we will see, by the Coronacrisis recovery plan.

\section{The first EU Coronavirus relief deal: a failure to get credit, a sentence to death?}

"Europe suffered a historic defeat on Thursday night" (The Guardian, Saturday $11^{\text {th }}$ April 2020). ${ }^{4}$ The first line of an article written by Yanis Varoufakis, former finance minister of Greece, immediately after the meeting of the Eurogroup on Thursday $9^{\text {th }}$ April 2020, gave voice to the hope, ambition and regret coming from the EU member states devastated by the impact of Covid-19 crisis. A shattered hope in a more supportive EU; a broken ambition for an "ever closer union among the peoples of Europe"; 5 a regret about the dramatic lack of "awareness of a common destiny" 6 that not only did the pandemic make clearer for European peoples, but for the humanity as a whole. The EU's Coronavirus relief deal, Varoufakis argued, "[b]esides constituting an epic dereliction of duty, ... dealt a decisive blow to the foundations of the European union - much to the delight of Europe's critics and enemies". ${ }^{7}$

Writing amid the general lockdown affecting continental Europe at the pick of the Corona crisis, ${ }^{8}$ Varoufakis pointed at the cowardice of many EU actors in (not) taking action in a decisive moment of history. The reasons underpinning this vital necessity to act, I believe, can be better understood by embracing a law-as-culture paradigm looking at the circulation of money (which by convention represents common needs and demand: Aristotle) not only as a crucial factor to

\footnotetext{
${ }^{4}$ Varoufakis: The EU's New Coronavirus Relief Deal.

${ }^{5}$ As declared in the Preamble of the founding Treaty of Rome of 1957.

${ }^{6}$ Solemn Declaration on EU, Stuttgart 1983.

${ }^{7}$ Varoufakis: The EU's New Coronavirus Relief Deal.

${ }^{8}$ With the real economy of goods and services hibernated by the lack of consumption and production, previsions of fall in GDPs and the highest rates of unemployment since WWII.
} 
protect the economy, but also to foster the legal, social and political values of community Life (see $\S 5)$.

In this light one may raise the question if some contradictions are still affecting or not the life of the Euro as currency of the EU market (polity?). In fact, if any lockdown "do[es] not care what currency we use" $" 9$ and polities like the US, Japan and the UK did already increase their public expenditures to counterbalance the falls in private incomes, the 19 countries of the eurozone were paradoxically hampered in their need for a massive boost in public debt by their arrangement of sharing a "(European) central bank that... has no common treasure to lean against and... is banned from backing directly the 19 treasuries that must borrow in euros to fight the crisis". ${ }^{10}$ Accordingly, a conundrum was actually faced by the weakest and most indebted Euro countries, such as Italy, Spain and Greece after the EU Coronavirus relief deal, as proposed on Thursday $9^{\text {th }}$ April 2020: they could issue new sovereign debt(s) to finance their economies (so to save their peoples from the depression of the Covid-19 crisis as only possible action to be undertaken), but with the fate not be able to repay their debt(s) (as a likely corollary for the action to be taken). Sovereign debt(s) that would have pushed these states into further austerity, depression or even default. Hence, what was presented as a triumphant agreement about an impressive sum of $€ 500 \mathrm{bn}$ to rescue Europe masked, in fact, the enchanting voices of Sirens luring EU states by the promise of salvation just to shipwreck their boats on the rocky coasts of the myth of the eurozone financial stability. In the middle of the Coronavirus perfect storm, the extension of "credit lines to countries such as Italy, via Europe's bailout fund (the European Stability Mechanism, ESM), to the tune of $2 \%$ of a recipient country's national income... [plus] more loans, of about $€ 100 \mathrm{bn}$, to the social security systems" ${ }^{11}$ had the (cruel) effect of reviving the spectrum of financial disintegration for weaker EU states. But, above all, it sounded to some ears as a death sentence by the Eurogroup to the greatest creation of international politics of the last century in Europe: the EU itself.

Indeed, the failure of an appropriate politics about giving credit to EU states ${ }^{12}$ sentenced, implicitly, the factual EU incapability to receive credit by its peoples - and so the end of an "even closer union" sustained (only) by a market nomos (as validity culture of its own

\footnotetext{
${ }^{9}$ Varoufakis: The EU's New Coronavirus Relief Deal.

${ }^{10}$ Ibid.

${ }^{11}$ Ibid.

${ }^{12}$ Despite a plurality of mechanisms being certainly advanced: from the ESM to the role of the EIB, the European Investment Bank; from the SURE, Support to mitigate Unemployment Risks in an Emergency, to the promise of a Recovery Fund.
} 
normativity) that has imperfectly backed the last 20 years of the EU polity by means of its nomisma, the Euro.

In a condition where "debt-sharing is banned by the treaties that created the Eurozone, at the insistence of the northern European countries running a trade surplus with the rest", the eurozone itself, as Varoufakis argued, "will remain an iron cage of austerity for most and a source of economic stagnation for everyone". ${ }^{13}$ In this situation, the demand for money (nomisma) through the issuance of so-called euro-bonds ${ }^{14}$ was killed by the EU nomos in a two-faced Janus's failure to get credit. $^{15}$ The inherent paradox of a nomos sentencing to death its own nomisma (and viceversa ${ }^{16}$ requires at this point further critique to shed light over what could have been the destiny of the EU without a radical change of the contents of the recovery deal at the end of May 2020 (see $\S 4$ ). An interpretation that the next section will advance in relation to the Roman figure of homo sacer as conceptualized by Giorgio Agamben.

\section{Homo Sacer, Sacred Euro}

When examined more carefully, the metaphor of the death sentence released by the Eurogroup on $9^{\text {th }}$ April looks less adequate than intended: in fact no trial was held; no judgement was enacted; no intention was formally addressed to declare the end of the Euro (the nomisma of EU economic order) nor of EU law (the nomos of Europe's legal, social and political order). More correctly, one could ascribe these consequences to the two sides of the same coin: the failure of the EU polity and its currency (its monetary nomos) derived from breaking the 'oath' of its origin as grounded on the pursuit of "an ever closer union among the peoples of Europe". ${ }^{17}$ Significantly, an ancient figure, that of the homo sacer in Roman law, may offer valuable hints to interpret what would have been the destiny of the EU in the Corona crisis (without a radical revision of the recovery plan: $\S 4$ ). Literally "sacred man", in antiquity the meaning of homo sacer was actually closer to the idea of "accursed man": being the oath essentially an act of conditional self-cursing by invoking one or more deities, the oath-breaker condemned himself to

\footnotetext{
${ }^{13}$ Varoufakis: The EU's New Coronavirus Relief Deal.

${ }^{14}$ Common debt instruments that allows long-term risk to shrink by transferring a portion of it from weaker to stronger Member States via risk-sharing.

15 (Not) giving economic credit to member states so (not) to receive political credit from European citizens.

${ }^{16}$ Causing, in the end, the self-defeat (suicide?) of the EU polity itself.

${ }^{17}$ Treaty of Rome.
} 
punishment without any emitted sentence. It was the act of oath-breaking itself to imply his sacertas, his status of outlaw deprived of civic rights. Self-responsible for the breaking of the pax deorum (the fundamental harmony between humans and gods in Roman ancient religion), the homo sacer was banned from the civitas, put outside the law (better, beyond it): hence, not only could he be killed by anybody without the killer being regarded as a murdered, but he neither could be sacrificed according to religious rituals (having lost the protection of the gods, he did not belong to human society anymore, nor he could be consecrated to a deity). In summary, the action of the homo sacer jeopardized the pax deorum, the harmony between men and gods, to the extent that the survival of the entire community of Rome was put in danger: his status of outlaw immediately related to his sacertas.

As well-known this obscure figure of ancient Roman law constitutes the starting point of the main work by Italian philosopher Giorgio Agamben's Homo Sacer: Sovereign Power and Bare Life. ${ }^{18}$ In positing fundamental questions about the nature of law and power in general, Agamben highlights the intrinsic paradox of the man 'under the spell' of the law by being excluded from it while being included in it at the same time (the homo sacer was within the juridical order only by being outside it, to wit, by its capacity to be killed by anybody) - the exact mirror of the 'spell' of the power for the sovereign, who stands within the law by being outside the law (through his political force to suspend law in a state of emergency). It is by qualifying human political life (in form of bios, hence the concepts of biopower and biopolitics in Agamben) that law operates via a simultaneous inclusion and exclusion of 'bare life' (the Greek zoe): by actively constructing the lives of political beings (citizens), while positing cases 'beyond the law' (the homo sacer and the sovereign) to re-affirm the nature of its ultimate power. Sovereignty, in the end, incorporates citizens in the bios of the political body by an original exclusion of the 'bare life', as much it embodies the power of the sovereign to suspend the law in the state of emergency (a concept expanded by Agamben in his State of Exception). ${ }^{19}$

It does not come as a surprise that the interpretive strength of Agamben's homo sacer contextualized in the emergency of the Corona crisis can shed light on the contradictory nature (and possible destiny) of the Euro when a parallelism is drawn from the category of law (nomos) to that of money (nomisma). Betraying its own raison d'être (the pursuit of "an ever closer union among the peoples of Europe"), the EU has posited in the original version of the Coronacrisis recovery deal its nomisma 'outlaw' (beyond its own nomos) by allowing the Euro to be borrowed

\footnotetext{
${ }^{18}$ Agamben: Homo Sacer.

${ }^{19}$ Agamben: State of Exception.
} 
by member states via sovereign debt(s), but without being expendable through the (economic, political, but also moral) credit of a unified polity as a whole. The myth of the EU shared sovereignty, dignified in hundreds of academic articles and books, has revealed itself as the enchanting singing of Sirens, since deprived of a mechanism of shared risk grounded on the monetary nomos of an (inexistent) unified EU sovereign debt (logical prerequisite for the issuance of euro-bonds in the form of 'corona-bonds', so to face the ongoing crisis). The substantial impact of the paradoxical nomos of the EU (allowing member states to deny the value of its own nomisma) can be deemed equivalent to a condition of sacertas where financial markets ${ }^{20}$ can attack the finances of weaker EU member states, while more stable EU members may protect (or even reinforce) their economies.

If the criticism about the economic implications of risk premium among financial instruments of EU member states (e.g. the spread between 10-year Italian bond and the benchmark of 10-year German Bund) has often been raised in the persistence of the validity the EU nomos, the emergency of the Corona crisis could have brought about the end of the pax deorum, i.e. the harmony between the 'gods' of the EU polity and the 'men' of EU citizens, rendering the Euro a kind of "sacred, accursed money". A nummus sacer that the global financial markets could have killed $^{21}$ while not being expendable 22 according to the shared rules of the EU budgetary policies (the 'rituals' at law).

The sacertas of the Euro in the Covid-19 recovery deal of $9^{\text {th }}$ April, in the end, has revealed the persistent contradictions of the EU nomos, whose 'positive money/law', while being 'ruled' by the sovereignty of founding treaties and an operating European Central Bank, is undermined by the 'natural money/law' still 'ruled' as store of value at the level of member states' sovereignty. ${ }^{23}$ Locating itself beyond the categories of positive/natural nomisma, the 'accursed destiny' of the Euro as sacred money could have found its death in the demolition of the EU polity and the new rise of nationalisms unless urgent action taken. In the end, what the Covid-19 emergency plan disclosed in its original version was how the EU Life still suffers from a bare

\footnotetext{
${ }^{20}$ I.e. the collective 'anybody' of capitalism deprived of immediate responsibility for 'killing' economic actors by bankruptcy.

${ }^{21}$ By killing the economies of weaker EU member states borrowing in Euro via their own sovereign debts.

22 'The expendables' of the EU budget as precise mirror of the 'one that can be sacrificed'.

${ }^{23}$ With stronger states maintaining an advantage over weaker states, and even reinforcing it in the crisis.
} 
credit (a sort of financial zoe) dependent (in terms of the political inexistence of the EU/Euro as a comprehensive nomos/nomisma) on the primacy of member states' sovereign (debts). ${ }^{24}$

\section{The Euro In-Between Rigor Mortis, Legal Order and Economic/Political Resurrection}

If the 'sacred money' paradigm may shed light over the 'death sentence' for the Euro in the original version of the Coronavirus relief deal, the bimester April-May 2020 (at the middle of which the European summit in charge for discussing the deal proposal took place on $23^{\text {rd }}$ April $2020)^{25}$ witnessed a turmoil in the Euro(/EU)'s struggle to survive: a turmoil from which some hope for a return to Life can be foreseen $(\S 5)$. The race to save the EU from the pandemic has seen some courageous actors debating against more conservative member states in a wake of the EU nomisma to become a vehicle for a re-generated EU nomos. Thus, in the middle of the negotiations not only did the rescue package become a factor of economy recovery, but also a fundamental opportunity of renovated political action, so to boost the transformation of the EU market (a Europe of traders) into the EU polity (a Europe of peoples).

On the one side of the Euro(/EU)'s struggle Pedro Sánchez (Spanish Prime Minister) called on Europe to produce a Marshall Plan to recover the continent's economies ( $5^{\text {th }}$ April 2020), echoed by Giuseppe Conte (Italian Prime Minister), as well as by Emmanuel Macron (President of France), who remarked how "[w]e are at a moment of truth, which is to decide whether the EU is a political project or just a market project. I think it's a political project... We need financial transfers and solidarity, if only so that Europe holds on" (16 ${ }^{\text {th }}$ April 2020). On the other side those who the chronicle re-named "the Frugal Four" in their attempt to keep a rigorous eye over the EU spending system ${ }^{26}$ were led by Mark Rutte (Dutch Prime Minister) in their strong resistance to any plan for euro-bonds or for sharing the costs of the pandemic. Next to the pressure from France, Spain and Italy to pledge solidarity, Paolo Gentiloni (former Italian Prime Minister and now the EU's Economy Commissioner) stressed how the Coronavirus crisis posed an "existential threat to the building of the Union" (13 ${ }^{\text {th }}$ May 2020). For the good luck of the EU, the austerity backed by the Frugal Four (some sort of 'rigor mortis' played over the body of the Euro, keeping the metaphor of the 'sentence to death': see $\S 2$ ) was strongly opposed by the

\footnotetext{
${ }^{24}$ Hence the bios of their own political/economic powers, witnessed by the spread in risk premiums, where stronger states are fated to overrule the economies of weaker states.

${ }^{25}$ Actually, the fourth virtual summit in seven-week time from the beginning of the crisis.

${ }^{26}$ Namely Austria, Denmark, Sweden and the Netherlands.
} 
German Chancellor, Angela Merkel, sustaining a common initiative with her French counterpart Emmanuel Macron (18 $8^{\text {th }}$ May 2020) for a recovery plan of $€ 500 \mathrm{bn}$ to collectively finance the EU response to the Coronavirus crisis by instruments of joint debt, direct grants (not debt, as in the original idea linked to the EMS) and an increased budget to sustain the weakest member states. The principle of austerity was then rapidly replaced by the re-discovery of a solidarity principle in a recall of the distant founding text of the EU, the Schuman Declaration of $9^{\text {th }}$ May 1950, urging after WWII that "Europe will not be made all at once... [but] through concrete achievements which first creates a de facto solidarity". ${ }^{27}$

Significantly for the intersection between the nomisma and the nomos in the eurozone, this reemergence of solidarity as core value backing the EU polity found at the beginning of May 2020 an obstacle precisely in the EU legal order. At that time the German constitutional court expressed concerns about the European Central Bank's plan (as announced by its President Christine Lagarde) to support the recovery with a credit line at the lowest interest rate by a quantitative easing strategy - as it could breach German law. The lack of a common EU debt (as background for the stability of the Euro) re-emerged as the reason for the sacertas of the Euro, with the European Commission President, Ursula von der Leyen, obliged to issue immediately an official statement warning of possible EU legal action against Berlin (so to protect the EU common market), and Angela Merkel promptly stepping in to try to find a way out of a bilateral damaging clash between Germany and Brussels.

In the peril of a debt shipwreck (see before, $\S 2$ ), the outcome of the negotiations led to a final proposal by the European Commission of a total of $€ 750 \mathrm{bn}$ recovery plan, split into $€ 500 \mathrm{bn}$ of grants for EU member states and $€ 250 \mathrm{bn}$ of loans at the end of May. As Ursula van der Leyen remarked, if the EU was facing against the pandemic a crisis that it had never seen before in 70 years, the recovery plan itself could be seen as a 'defining moment' in the EU history. In fact, although the term 'euro-bonds' was not mentioned, the extra EU debt was going to be serviced by new EU taxes, ${ }^{28}$ so defining a nascent economic/political resurgence ${ }^{29}$ linking the "return to Life' of the Euro to the intersection between money, taxes and debt as backbone for a renewed EU polity (see $\S 5$ ). While the European Central Bank agreed to inject an additional $€ 600 \mathrm{bn}$ of emergency financial support into the EU market, it is precisely within the background of the

\footnotetext{
${ }^{27}$ Schuman: The Schuman Declaration.

${ }^{28}$ Such as corporate levies, a plastics tax or charges on imported goods with a high carbon footprint.

${ }^{29}$ Or even resurrection from death.
} 
$€ 750$ bn rescue program by the EU Commission that a historical change can actually be foreseen for the EU polity through the coherent integration of its nomisma and nomos.

\section{Conclusions. Back to Solidarity? Life, Gift and a Historic Opportunity for the EU Polity}

The turmoil that the Euro has experienced in the negotiations for the Coronavirus recovery plan has been summarized in this paper as a 'threat to death' $(\S 2)$ that the EU nomisma has faced because of the EU nomos. In this regard, the metaphor of the 'sacred Euro' as economic/political counterparty of Agamben's homo sacer ( $\$ 3$ ) has been functionally oriented to depict this destiny, but also to highlight a potential resurgence of the EU polity by a new system of grants, shared debt and loans that seems to pave the way for the future of the eurozone $(\S 4)$.

In this light, we can better understand at this point not only Varoufakis's words ${ }^{30}$ (§ 2 ) but also the warning launched at the end of April 2020 (immediately after the EU summit of $23^{\text {rd }}$ April) by Shahin Vallée, French economist and former adviser to Emmanuel Macron.

The European summit last week was hailed as a moment of truth. [...] The leaders agreed on an economy recovery plan that is incomplete and unbalanced, and is planting the seed of profound divergence between member states. [...] [E]ach government's ability to support economy recovery will be highly constrained by their level of debt... [with a] long-term unsustainable debt burden that the crisis will create. In the absence of true mutualisation... and real monetisation, European countries will either spend the next generation in austerity and depression..., or they will go through the socially and politically destructive restructuring of some of it. [...] The eurozone needs to move towards a true form of fiscal federalism under the democratic control of the European parliament with taxing, borrowing and spending powers, with the current EU budget doesn't permit. Short of that, the EU will carry on on its crutches, medically assisted by the drip-feed of a central bank that is forced to provide the vital energy to a political project that has lost its soul. ${ }^{31}$

\footnotetext{
${ }^{30}$ Varoufakis: The EU's New Coronavirus Relief Deal.

${ }^{31}$ Vallée: Coronavirus has Revealed the EU's Fatal Flaw.
} 
It is by elaborating on these reflections in the light of the nature of money as the 'life of goods' by circulation that the risk for the EU to lose its soul (as a sort of Mozart's Don Giovanni devastated by the sacertas of its nomisma) can be providentially translated into an opportunity for a historic change. A radical transformation of the rationale of its nomos, from the EU market to the EU polity, where the Coronacrisis recovery plan $^{32}$ can work as a 'return to Life' through the reappearance of solidarity as founding value of the EU polity.

In an essay originally published in 1976 under the title Geld oder Leben: Eine metaphorologische Studie zur Konsistenz der Philosophie Georg Simmel, ${ }^{33}$ the influential postwar German cultural theorist Hans Blumenberg highlights how money stands as Simmel's 'proto-metaphor' for Life in the latter's nascent Lebensphilosophie. Accordingly, as noted by Robert Savage, precisely like money, in Simmel's scholarship Life itself "turns out to be pure circulation, sociation, and interactivity, an endless cycle of extensions and intensifications of value emerging through processes of social exchange". ${ }^{34}$ So, in Blumenberg's interpretation "the two key concepts in Simmel's intellectual development - first value, then life - ... [are] mediated by the theme of money [through the publication of his famous Philosophie des Geldes], ${ }^{35}$ which was meant originally to provide access to the concept of value and ended up forcing a path to the concept of life". ${ }^{36}$ In a period where collective Life is put at stake by a global pandemic and shadows of death may obscure the legitimacy of the sovereign power (as claimed in the noteworthy book Necro-Politics by Achille Mbembe), ${ }^{37}$ looking for the reemergence (or even resurrection) of Life "through processes of social exchange", circulation, sociation and interactivity, requires to re-think (better, to re-affirm) the role of money in shaping the normative order of a community and how EU money exercises a fundamental function in maintaining the stability of the EU order.

The impasse by the Eurogroup decision of Thursday $9^{\text {th }}$ April in taking more ambitious choices for the future of the EU polity (by not conceiving the Euro as core metaphor of the political Life of the EU) may have caused a destiny of sacertas that is inherently connected to the oathbreaking of its pursuit of "an ever closer union among the peoples of Europe". Left within the

\footnotetext{
${ }^{32}$ By means of the provision of $€ 500 \mathrm{bn}$ of grants for the most affected EU member states: under the Commission's blueprint, Italy will get $€ 82 \mathrm{bn}$, Spain $€ 77 \mathrm{bn}$, France $€ 39 \mathrm{bn}$, Poland $€ 37 \mathrm{bn}$ and Germany $€ 29 \mathrm{bn}$.

${ }^{33}$ And later translated into English by Robert Savage: see Blumemberg: Money or Life.

${ }^{34} \mathrm{Ib} .$, p. 249.

${ }^{35}$ Simmel: The Philosophy of Money.

${ }^{36}$ Blumemberg: Money or Life, p. 249.

${ }^{37}$ Mbembe: Necropolitics.
} 
realm of 'positive money' (as a currency dependent on the 'positive laws' of members states' treaties) only by excluding its nature of 'natural money' (since the implications of excessive sovereign debts for weaker member states would have implied a reality of recession contrary to the function of any monetary nomos), the Eurozone, as the place of sacred money, would have suffered from intrinsic instability due to the attacks by speculators in the global financial market. Precisely, the metaphor of the life of the homo sacer equals here the Life of the Euro as nummus sacer: money not expendable by the EU polity, whose collective bare credit is specular to the individuality of member states' sovereign (debts).

With a pandemic bringing mass death and economic catastrophe, while the draft of the recovery plan $\left(9^{\text {th }}\right.$ April) was utterly disappointing $(\S 2),{ }^{38}$ the deep meaning of the radical innovations embodied in its final version $(\S 4)$ can be better understood through another masterpiece of economic anthropology, namely Marcel Mauss's Essai sur le Don. ${ }^{39}$ In some fortunate ways, in fact, the rationales of The Gift as 'form and reason for exchange' illuminated the European summit of $23^{\text {rd }}$ April 2020, shaping the future of the eurozone and of the EU polity as a whole. The European Council faced at that precise moment the responsibility to free the EU still jailed in nationalistic sovereign debts (each confirming the sovereign power, the 'positive laws' of the states) towards the transformation of its bare credit into the qualified Life (in terms of "natural law' and political bios) of an "ever closer union among the peoples of Europe". That moment was a historic choice between a destiny of sacertas for the Euro or of resurrection for the EU. Then, the correspondence between giving (economic) credit and receiving (political) credit suggested that braver actions were necessary for the survival of the EU nomos by means of its nomisma. And to this aim, the exchange of 'gifts' (i.e. the acceptance of mechanisms of shared risk connected with the shared sovereignty of which the EU is entitled), with the obligation to reciprocate beyond the strict rules of financial capitalism (on which the logic of the sovereign debt is grounded), became be the only possibility for the extension of the Life of the EU system beyond the necro-politics of the Corona crisis.

It is by reading Mary Douglas's Foreword to Mauss's The Gift, I believe, that the paradigm of law-as-culture can offer further support to interpret the future of the EU polity beyond its 'sacred Euro'. By commenting Mauss's work, Mary Douglas remarks how in any functioning

\footnotetext{
${ }^{38}$ Tthe "EU's response to the pandemic has been depressingly slow, hesitant, stingy and unsupportive" wrote Javier Cercas in The Guardian, $15^{\text {th }}$ April 2020 (Cercas: The EU was Created to Keep Nationalism in Check).

${ }^{39}$ Mauss: The Gift.
} 
community there are no free gifts, as only by means of reciprocity and counter-exchanges (i.e. by returning the gift) mutuality can be promoted among the members of the society: expecting the recipient from any return, "puts the act of giving outside any mutual ties. [...] A gift that does nothing to enhance solidarity is a contradiction". ${ }^{40}$ If a striking parallelism can be drawn between the gift's mechanism of giving and returning and the nature of currency (nomisma) as 'monetary nomos' (in the bilateral correspondence of people giving political credit to the sovereign so the receive economic credit through money: see $\S 1$ ), it is again in the idea of reciprocity that a great lesson can be drawn from the Coronavirus recovery plan, and a great opportunity for a historic change for the EU polity may be carried out as well.

In this regard, Ferdinando Giugliano, Bloomberg Opinion Editor and former member of the editorial board of the Financial Times, has significantly written that the rescue fund "would break many taboos, possible paving the way for EU taxes and EU treasury". ${ }^{41}$ The final deal that followed Ursula von der Leyen's proposal, in fact, could mark a radical transformation (a new Life) for Europe.

The fund breaks a number of EU taboos. First, it raises significantly the amount the Commission can borrow on the financial markets. These are not "euro bonds" in the classic sense of the word... [...]. However, it will be a very useful blueprint if the euro zone chooses to move closer to a much-needed fiscal union. The second big change is that twothirds of the money would [be] given away as grants. This is the most controversial part of the plan, and it risks being watered down in the forthcoming negotiations between member states. [...] But the generous provision of grants is a step change from the European Stability Mechanism, the euro area's rescue fund, which only offers loans. The final taboo to be possibly broken is on EU-wide taxation. ${ }^{42}$

Waiting for the rescue of the sacred Euro and an economic resurrection of the EU from the Coronavirus pandemic, a political metamorphosis may actually take place, where the provision of grants may settle the solidarity of Schuman Declaration 'back to the future' of the EU by strengthening mutual ties (EU taxation, EU shared debt, EU fiscal union) on the grounds that gifts that do not enhance solidarity are, indeed, a contradiction (see Douglas, above).

\footnotetext{
${ }^{40}$ Douglas: Foreword, pp. $\mathrm{x}$ f.

${ }^{41}$ Giugliano: The European Union Is on the Brick of Historic Change.

${ }^{42} \mathrm{Ib}$.
} 
Hence, in challenging the sacertas of the Euro and in the wake for a common response to a global threat, for once "political stars may be aligned. If so, 2020 might be remembered in Europe as more than just the year of the pandemic". ${ }^{43}$ As stars can lead sailors in their common journey, saving them from the perils of the sea and the danger of shipwrecking, this might be, indeed, a historical opportunity for the EU to move from the EU market to a coherent EU polity by a new nomos backing its nomisma.

After 70 years from WWII, the common destiny of European citizens will depend, once again, on how the stars of the EU flag will direct their path.

\section{References}

Agamben, Giorgio: Homo Sacer. Sovereign Power and Bare Life, Stanford 1998 [transl. by Daniel Heller-Roazen from the original Italian version: Homo Sacer. Il Potere Sovrano e la Nuda Vita, Torino 1995].

Agamben, Giorgio: State of Exception, Chicago 2005 [transl. by Kevin Attell from the original Italian version: Stato di Eccezione, Homo Sacer, II, I, Torino 2003].

Aristotle: The Nicomachean Ethics, London 2004 [transl. by J.A.K. Thomson; revised by Hugh Tredennick; introduction and further readings by Jonathan Barnes: 2004].

Blumenberg, Hans: Money or Life: Metaphors of Georg Simmel's Philosophy, in: Theory, Culture \& Society, 29(7/8), 2012, pp. 249-262 [transl. from the original German version, 1976, by Robert Savage].

Cercas, Javier: The EU was Created to Keep Nationalism in Check. Coronavirus is a Dangerous Test, in: The Guardian, 15.04.2020, https://www.theguardian.com/books/2020/apr/15/the-euwas-created-to-keep-nationalism-in-check-coronavirus-is-a-dangerous-test; last accessed 12.05.2020.

Douglas, Mary: Foreword. No Free Gifts, in: Mauss, Marcel: The Gift. The Form and Reason for Exchange in Archaic Societies, London \& New York 1990, pp. ix-xxiii.

\footnotetext{
${ }^{43} \mathrm{Ib}$.
} 
Giugliano, Ferdinando: The European Union Is on the Brick of Historic Change, in: Bloomberg 31.05.2020, https://www.bloomberg.com/opinion/articles/2020-05-27/eu-pandemic-recoveryfund-puts-europe-on-brink-of-historic-change; last accessed 05.06.2020.

Mauss, Marcel: The Gift. Forms and Functions of Exchange in Archaic Societies, London 1954 [transl. by Ian Cunnison from the original French version: Essai sur le Don. Forme et Raison de l'Échange dans les Sociétés Archaïques, in: Année Sociologique, 1923-1924].

Mbembe, Achille: Necropolitics, Durham/NC 2019.

Schuman, Robert: The Schuman Declaration, 09.05.1950, https://europa.eu/europeanunion/about-eu/symbols/europe-day/schuman-declaration_en; last accessed 03.06.2020.

Simmel, George: The Philosophy of Money, London 1978 [transl. by Tom Bottomore and David Frisby from the original German version: Philosophie des Geldes, 1900].

Solemn Declaration on European Union, European Council, Stuttgart 19 June 1983, available online at aei.pitt.edu/1788/1/stuttgart_declaration_1983.pdf; last accessed 01.06.2020.

Treaty of Rome - Treaty Establishing the European Economic Community (EEC Treaty), https://eur-lex.europa.eu/legal-content/EN/TXT/?uri=LEGISSUM\%3Axy0023; last accessed 03.06.2020.

Vallée, Shain: Coronavirus has Revealed the EU's Fatal Flaw: The Lack of Solidarity, in: The Guardian, 28.04.2020, https://www.theguardian.com/commentisfree/2020/apr/28/eucoronavirus-fund-share-crisis-soul-european-parliament-fiscal; last accessed 25.05.2020.

Varoufakis, Yanis: The EU's New Coronavirus Relief Deal is a Gift to Europe's Enemies, in: The Guardian, 11.04.2020, https://www.theguardian.com/world/commentisfree/2020/apr/ 11/eu-coronavirus-relief-deal-enemies-debt-eurozone; last accessed 20.05.2020. 